\title{
Direct cardiovascular effects of glucagon like peptide-1
}

Asfandyar Sheikh

\begin{abstract}
Current gold standard therapeutic strategies for T2DM target insulin resistance or $\beta$ cell dysfunction as their core mechanisms of action. However, the use of traditional anti-diabetic drugs, in most cases, does not significantly reduce macrovascular morbidity and mortality. Among emerging anti-diabetic candidates, glucagon like peptide-1 (GLP-1) based therapies carry special cardiovascular implications, exerting both direct as well as indirect effects. The direct cardiovascular effects of GLP-1 and its analogs remain the focus of this review.
\end{abstract}

\section{Article}

Cardiovascular disorders (CVDs) are the leading cause of adult mortality and morbidity worldwide, accounting for 17 million deaths (30\% of all deaths) in 2008 [1]. CVDs pose a significant economic burden on the healthcare systems of both developing and developed countries. According to an estimate by the American Heart Association (AHA), the annual US medical costs for cardiovascular diseases are likely to increase to over USD 800 billion in 2030, which is nearly triple the amount spent in 2010 (USD 272 billion) [2]. Risk factors of CVDs, which are grouped into modifiable and non-modifiable, include hypertension, smoking, hyperlipidemia, being overweight and having a sedentary lifestyle. Most of these risk factors overlap with those of type 2 diabetes mellitus (T2DM) and past studies have demonstrated such a strong relationship between these two entities that AHA has declared "diabetes is a cardiovascular disease" [3].

Recent advancements in healthcare have witnessed an improvement in the prognosis of T2DM patients due to earlier detection and improvements in diabetes care [4]. However, the rationale of intensive anti-diabetic therapy has been challenged in multiple studies. The ACCORD study was conducted on patients with T2DM having HbA1c concentrations $>7 \cdot 5 \%$ and established cardiovascular disease or $\geq 2$ cardiovascular risk factors in order to determine whether a more intensive therapeutic strategy was associated with a reduction in the

Correspondence: asfandyarsheikh@gmail.com

Dow Medical College, Dow University of Health Sciences, Baba-e-Urdu Road, Karachi, Pakistan rate of cardiovascular events [5]. The study, which ended prematurely due to a higher mortality rate in the intensive treatment group, failed to report significant reduction in major cardiovascular events, giving a notion that intensive therapy was associated with significant harm in high risk patients [6].

Current gold standard therapeutic strategies for T2DM target insulin resistance or $\beta$ cell dysfunction as their core mechanisms of action. For instance, biguanides and thiazolidinediones, also called "sensitizers", act by reducing hepatic glucose output and promoting uptake of glucose by the periphery. Similarly, another class of drugs, called "secretagogues", acts by triggering insulin release from the pancreatic $\beta$ cells. However, the use of traditional antidiabetic drugs, in most cases, does not significantly reduce macrovascular morbidity and mortality. This notion has led researchers into searching for alternatives that provide substantial benefits without the added side effects. This idea is especially significant because of the fact that T2DM and cardiovascular diseases are almost invariably related. Among emerging anti-diabetic candidates, glucagon like peptide-1 (GLP-1) based therapies carry special cardiovascular implications (Figure 1).

\section{The incretin effect}

It is a well-known fact that oral administration of glucose is a more potent stimulus for insulin secretion than parenteral infusion [8]. This notion implies the presence of an accessory secretory stimulus from the gastrointestinal tract, unrelated to blood glucose levels. The term "incretin effect" refers to a concept which postulates that a family of endocrine factors is responsible for inducing 


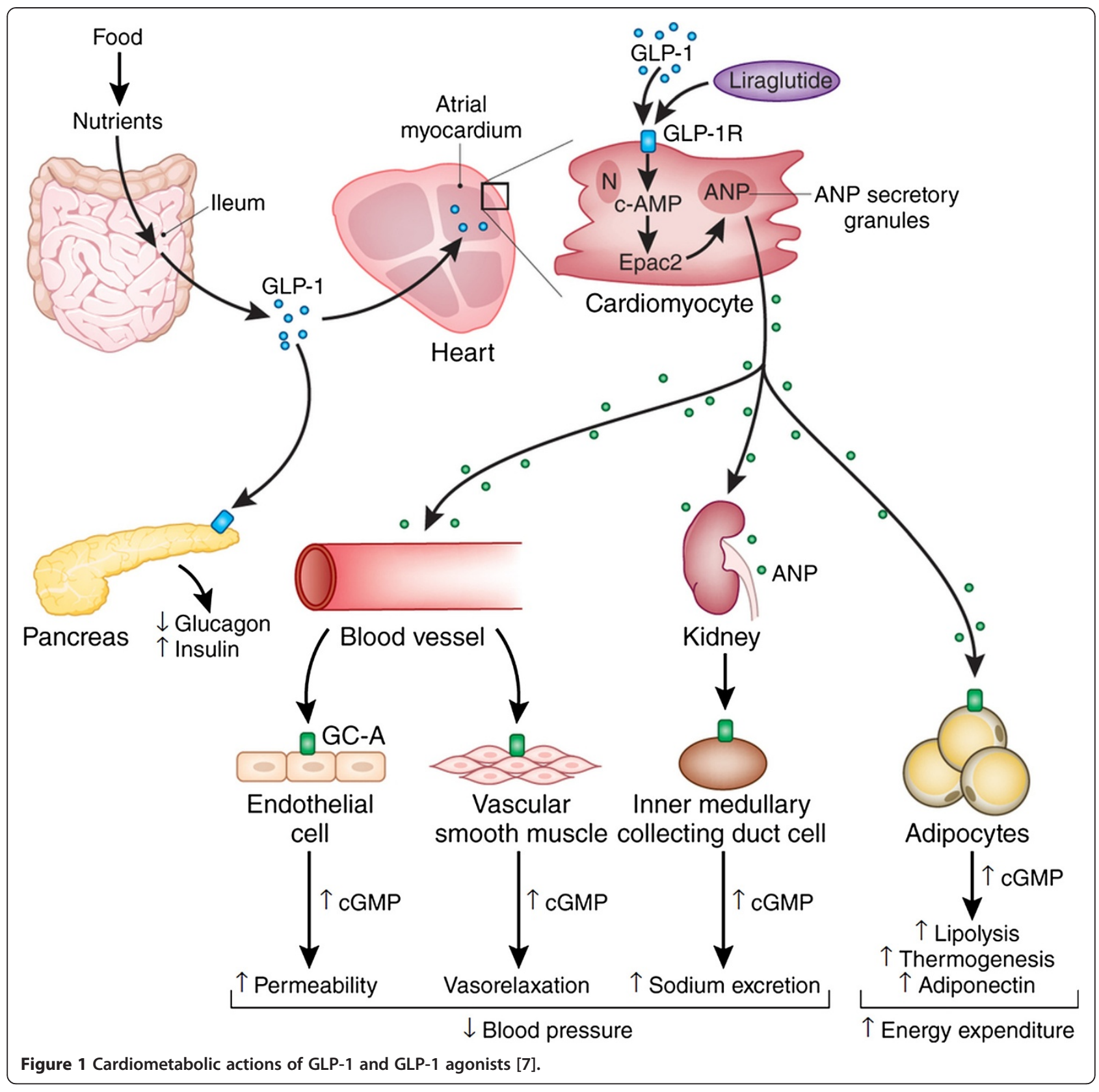

an insulin response before a rise in blood glucose levels [9]. However, the term is somewhat vague, given the fact that incretins have been increasingly reported to have certain non-glucose-lowering functions such as the expansion and preservation of pancreatic $\beta$ cell mass, bone metabolism, neuroprotection and cardioprotection $[10,11]$.

The main hormones in the group include glucosedependent insulinotropic polypeptide (GIP) and glucagonlike peptide-1 (GLP-1). GIP is a 42 amino-acid peptide hormone released from the $\mathrm{K}$ cells of the proximal intestine. Although the main action of GIP is to provide a stimulus for the release of insulin after an oral glucose challenge, the hormone has also been reported to promote lipid uptake in adipocytes [12]. GIP has also been found to exert influence over other tissues such as bone, although its extraglycemic profile is quite limited and largely preclinical in nature compared to its much celebrated partner GLP-1 [13].

GLP-1 is a derivative of the transcription product of proglucagon gene and is synthesized mainly by the $\mathrm{L}$ cells of ileal mucosa. The full length N-terminal extended forms of GLP-1 (1-37 and 1-36) are biologically inert. However, removal of the first 6 amino acids yields shorter compounds (7-37 and 7-36) that have enhanced biological activity [14]. Further cleavage of the first two $\mathrm{N}$-terminal amino acids results in the formation of GLP- 
(9-36) which is the major circulating form [15]. Like GIP, GLP-1 is released in response to ingestion of nutrients and acts on pancreatic $\beta$ cells to stimulate insulin secretion. Both have short half-lives because of rapid enzymatic inactivation mainly by dipeptidyl peptidase-4 (DPP-4). However, unlike GIP, GLP-1 has not been found to have a direct role in fat deposition in adipose tissues [16]. Furthermore, while GIP augments postprandial glucagon response, GLP-1 extenuates it [17-19]. Similarly, GIP promotes bone formation while GLP-1 inhibits it [20]. Both GIP receptor (GIPR) and GLP-1 receptor (GLP1R) belong to the G-protein coupled receptor family that function by activating adenylate cyclase causing increased levels of intracellular cyclic adenosine monophosphate (cAMP) and activation of protein kinase A (PKA) [21]. Both have been found to be associated with improved cognitive function due to their expression in brain tissue [22-24]. However, unlike GIPR, GLP-1R are present in several other tissues such as peripheral nervous system, lung and heart (Figure 2) [19].

GLP-1 based anti-diabetic therapies may be divided into two main groups: GLP-1 agonists and DPP-4 inhibitors (Figure 3). Exenatide and liraglutide, which belong to the first category, have already been approved by the FDA for the treatment of T2DM. These drugs are homologous (53\% and 97\% respectively) to natural GLP-1, with the added benefit of resistance to degradation by DPP-4 which enhances their half-life. Sitagliptin, vildagliptin, saxagliptin and linagliptin (DPP-4 inhibitors) have also been FDA approved, while others are undergoing trials [26]. The prospects for these drugs are quite exciting, especially for those with superimposed CVDs, given the fact that these drugs provide an added advantage of cardioprotection via different yet intricately related mechanisms.

\section{Direct cardiovascular effects of GLP-1}

Previous researches have demonstrated the presence of high-affinity receptors for GLP-1 in both human and animal models of hearts and vascular tissues, although the receptors were not localized until later by Ban et al. to cardiomyocytes, endothelium, and vascular smooth muscle cells [28-31]. The presence of these receptors suggests the possibility of prospective drug targets for

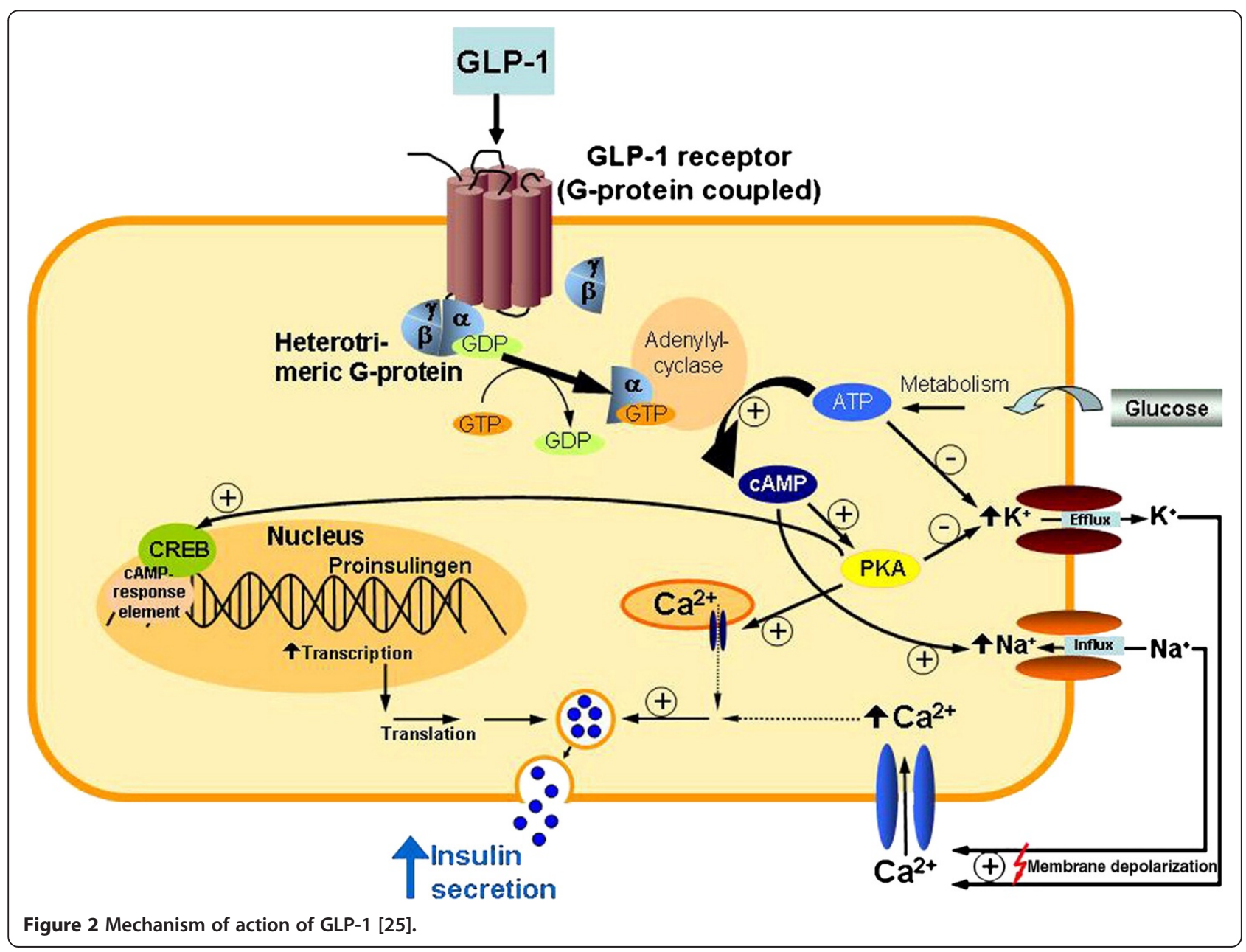




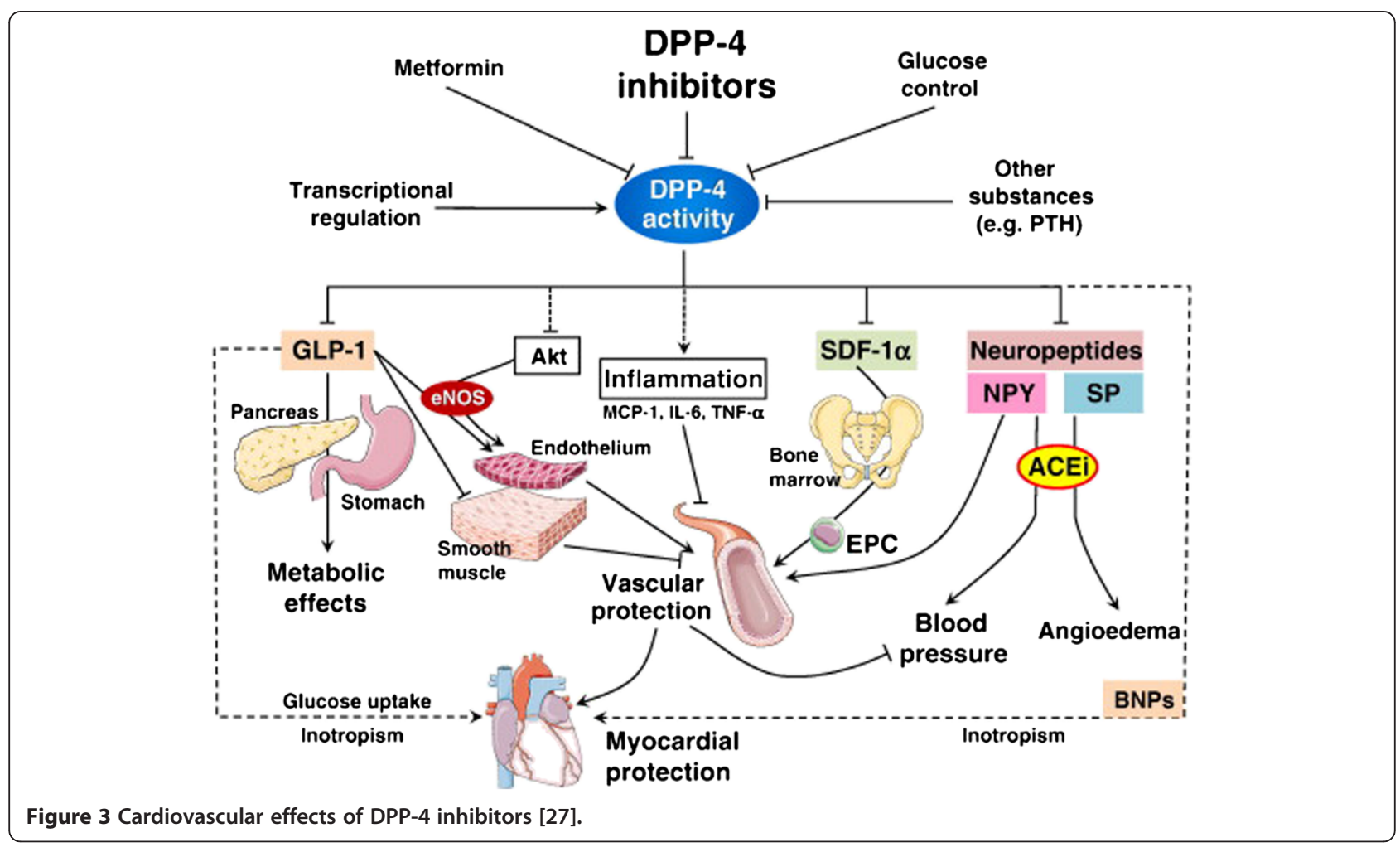

heart failure and other CVDs both in the presence or absence of pre-existing T2DM.

\section{Effects on myocardium \\ Electrophysiologic effects}

GLP-1 infusions in murine models have been reported to cause a dose-dependent inotropic and chronotropic effect. However, the existence of direct effects on cardiovascular system remains controversial due to conflicting results for in vivo and in vitro studies. For example, Barragan et al. and Yamamoto et al. demonstrated sympathomimetic mechanisms to be responsible for inotropic and chronotropic effects in murine models in vivo, and others such as Ahren et al. demonstrated similar effects that were not suppressed by reserpine, propranolol, or phentolamine, thereby suggesting a direct mode of action [32-34]. These findings was further supported by the study of Gros et al. who demonstrated a diminished basal heart rate and diastolic dysfunction after insulin administration in GLP-1R knockout mice [35]. However, experiments conducted in other settings have yielded contradictory results. For example, Deacon et al. failed to demonstrate similar effects in pig models while Vila Petroff et al. reported negative inotropic effects in rat myocyte cultures [36,37]. Similarly, cardiovascular benefits independent of GLP$1 \mathrm{R}$ activation have also been demonstrated [38].
Findings from human trials have demonstrated only a modest effect of GLP-1 analog administration on heart rate. In a placebo-controlled trial conducted on subjects with T2DM already receiving anti-diabetic therapy, exenatide administered subcutaneously demonstrated no clinically significant effects on heart rate [39]. Exenatide and liraglutide have been found to have no significant effect on QT interval in trials using moxifloxacin as a positive control [40]. Similar effects have been noted with DPP-4 inhibitors such as sitagliptin and vildagliptin, whereby supratherapeutic doses have succeeded in producing only a minor increase in the QT intervals [41,42].

The effects of GLP-1 infusion have also been studied on animal models of arrhythmias. Dokken et al. observed an amelioration of coronary flow reserve on administration of GLP-1 in pigs with a few minutes of untreated ventricular fibrillation followed by resuscitation [43]. However, no significant improvement was found in myocardial function [43]. Similar findings were reported by who attributed the improvement in coronary function to reduced markers for reactive oxygen species [44]. Human studies on the potential uses are scarce. A study conducted on patients scheduled to undergo coronary artery bypass graft demonstrated reduced occurrence of arrhythmias in those infused with GLP-1 compared with controls [45]. A patent has been registered for treatment of arrhythmias with GLP-1 agonists [46]. 


\section{Cardioprotective functions during ischemia/reperfusion}

Various theories have been put forward to explain the protective effects of GLP-1 on myocardium. The most upheld revolves around cardiac metabolism [47]. Under normal physiological conditions, cardiomyocytes utilize fatty acids as a fuel for energy [48]. During acute ischemia, they switch to carbohydrate metabolism, which eventually leads to insulin resistance [48]. GLP-1 analogs, such as liraglutide, have been shown to ameliorate insulin resistance and inflammation in previous studies [49]. This attenuation of insulin resistance, therefore, plays a favorable role in cardioprotection [50]. Another proposed mechanism that involves improved glucose uptake is related to the increase in glucose transport proteins (GLUT-2 and GLUT-4) by GLP-1 [51]. In patients with T2DM, GLUT-4 expression is markedly reduced, and GLP-1 mediated up-regulation of GLUTs, especially in cardiomyocytes, helps preserve their integrity [52]. GLP-1 has also been demonstrated to decrease lactate and pyruvate concentrations, thereby providing another mechanism for cardioprotection via improvement in metabolism [53].

Anti-apoptotic mechanisms have also been proposed. The first mechanism involves activation of cAMP and PI-3 K pathways via GLP-1R [54]. Bose et al. demonstrated a reduction in infarct size on administration of GLP-1 both in vitro and in vivo. This effect was abrogated in the hearts in vitro by GLP-1 receptor antagonist, cAMP inhibitor and PI-3 K inhibitor [55]. Other pathways and mediators have also been demonstrated to play a role. For example, Bose et al. demonstrated inhibition of GLP-1 mediated cardioprotection after administration of rapamycin, suggesting a role of mTOR/p70s6 kinase pathway. In an experimental study conducted by Noyan-Ashraf and colleagues, Liraglutide upregulated the independent expression of cardioprotective genes, including Akt, PPAR $\beta-\delta$, Nrf-2, and $\mathrm{HO}-1$, while suppressing the expression of GSK3 $\beta$ and activation of caspase-3 in murine hearts [56]. This effect was also found to be superior to metformin's in diabetic mice hearts [56]. Exenatide, another GLP-1 analog, has also been shown to provide cardioprotection via similar mechanisms [57]. Timmers et al. reported reduction in myocardial infarct size and prevention of deteriorated cardiac function on exanatide treatment in porcine model of ischemia/reperfusion [58]. This was associated with an increase in phosphorylated Akt and Bcl-2 expression as well as superoxide dismutase and catalase activity, and a decrease in active caspase 3 expression. Serum insulin levels were also increased without a corresponding change in glucose levels. The cardioprotective function of exendin-4 during hyperglycemic states was further elaborated in a recent study conducted by Younce, whereby exendin- 4 was found to improve cardiac function by inhibiting thapsigargin-mediated decrease in SERCA2a mRNA and via active phosphorylation of phospholamban [59]. Sitagliptin and vildagliptin have also been shown to reduce infarct size in various animal studies [60-62]. Anti-inflammatory mechanisms via attenuation of neutrophil activation were demonstrated by Dokken et al. in a rodent ischemia-reperfusion model, who reported a reduced expression of CD11b in rats receiving GLP-1 therapy [63].

Human studies have also provided evidence for cardioprotective functions of GLP-1 analogs and DPP-4 inhibitors in both diabetics and non-diabetics, although larger, randomized trials are still required. In the EXAMI study, Bernink et al. demonstrated that although high dose exenatide treatment did not exercise a significant effect on left ventricular function or area at risk, a trend was observed towards a smaller infarct size as percentage of the area at risk in patients with first acute myocardial infarction who were to be treated with primary percutaneous coronary intervention [64]. Lonborg and colleagues demonstrated a reduction in infarct size and increased myocardial salvage on exenatide administration in a randomized, placebo-controlled trial in human subjects with ST elevation myocardial infarction undergoing primary percutaneous coronary intervention [65]. Improvements in regional and global left ventricular function were observed by Nikolaidis et al. in human subjects with acute myocardial infarction infused with native recombinant GLP-1 for 72 hours following angioplasty [66]. These effects were independent of location of infarct or diabetic status of the patients [66]. Similar effects were demonstrated by investigators, both before and after revascularization procedures $[67,68]$. In a retrospective analysis of the IMS LifeLink ${ }^{\text {Tu }}$ database conducted by Best et al., patients on exenatide were less likely to have a major cardiovascular event, and had reduced risk of hospitalization compared with those receiving other anti-diabetics [69].

DPP-4 inhibitors have also shown encouraging results in human studies. In a placebo-controlled trial conducted on patients having pre-existing coronary artery disease with preserved left ventricular function, increase in GLP-1 levels caused by DPP-4 inhibition resulted in improvement of global and regional left ventricular function and amelioration of post-ischemic stunning [70]. New horizons are being explored in this regard, with a recent study providing promising results in the combination trial (SITAGRAMI-Trial) of sitagliptin and G-CSF based stem cell mobilization [71].

\section{Cardioprotective functions in heart failure}

Both preclinical and clinical studies have demonstrated beneficial effects of GLP-1 on the failing heart. Most of these studies identify attenuation of insulin resistance as 
the primary mechanism of action [72]. In a study published in 2004, Nikolaidis et al. demonstrated improvement of cardiac output, systolic/diastolic function and other hemodynamic parameters after infusion of recombinant GLP-1 in canine models of pacing-induced dilated cardiomyopathy [50]. These results were further supported by another study from the same lab, whereby GLP-1 was shown to stimulate myocardial glucose uptake via mechanisms that were p38 $\alpha$ MAP kinase and NO dependent, but independent of adenylyl cyclase or Akt [73]. These results have been successfully replicated in studies using other animal models. Vyas et al. reported improved glucose tolerance, cardiac contractility, and survival after infusion of exenatide in murine model of dilated cardiomyopathy [52]. Although the expression of myocardial GLUT4 was upregulated, no significant differences were found in the total myocardial GLUT1 levels between groups [52]. Another important finding of this study was that exenatide was also found to abolish the harmful effects of ritonavir (GLUT4 antagonist) on survival [52]. Poornima et al. demonstrated greater survival, preserved LV function, decreased myocyte apoptosis and reduced caspase-3 activation on chronic GLP-1 infusion in spontaneously hypertensive, heart failure prone rats [74]. Additionally, increased plasma insulin, decreased triglycerides, and improved myocardial glucose uptake were observed in the GLP-1 treated group [74]. Similar results were reported by Liu and colleagues [75].

DPP-4 inhibition has also yielded positive results. For example, Shigeta et al. observed reversal of diastolic ventricular dysfunction in a rat model due DPP4 inhibition, via local actions on angiogenesis and inotropic effects [76]. Similar results were reported by Gomez et al. who observed preservation of glomerular filtration rate, increase in stroke volume, and enhancement of the inotropic effect of exogenous brain natriuretic peptide due to DPP-4 inhibition [77].

Earlier studies have hinted towards improved myocardial function with reasonable tolerability in heart failure patients infused with GLP-1 [78]. For example, Sokos et al. reported improved left ventricular ejection fraction, myocardial ventilation oxygen consumption, 6-minute walk distance and quality of life in both diabetic and non-diabetic, class II/IV heart failure patients infused with GLP-1 [79]. However, Halbirk et al. reported only minor cardiovascular effects despite increased insulin levels and reduced plasma glucose concentration, in patients without diabetes but with compensated heart failure [80]. Similarly, in another study conducted by Nathanson et al., infusion of exenatide in male type 2 diabetic patients with chronic heart failure exhibited positive chronotropism and favorable effects on the cardiac index and hemodynamics; however, the definitive effects of exenatide in such patients were still inconclusive [81]. This notion implies that, although favorable results have been reported for clinical studies, the paucity of existing data warrants the need for further ventures in order to further elucidate the favorable effects of GLP-1 in heart failure patients [82].

\section{Effects on vasculature \\ Vasoprotective actions against endothelial dysfunction and atherosclerosis}

Endothelial dysfunction, characterized by impaired vasomotility and an increase in pro-coagulant and proinflammatory mediators, is a key feature of T2DM [83]. The robust relationship between these two entities has been largely attributed to oxidative stress caused by hyperglycemia, although a few studies have failed to demonstrate a significant reduction in cardiovascular risk as a result of intense glycemic control [84-86]. A strong association also exists with obesity and insulin resistance [87].

Atherosclerosis is the hardening of arterial wall due to progressive accumulation of fatty substances. It is caused by the interplay between endothelial cells, vascular smooth muscle and macrophages. Since reduced anti-coagulant properties and increased pro-inflammatory mediators and reactive oxygen species play important roles in the development of both endothelial dysfunction and atherosclerosis, the association between the two is almost ubiquitous [88].

Newly published reports are improving our understanding of the role of GLP-1 and its analogs in the improvement of endothelial function. For example, in a study conducted by Nathanson et al. on rat conduit arteries ex vivo, exenatide was not found to significantly ameliorate triglyceride-induced endothelial dysfunction nor did it exert a potent vasorelaxant effect [89]. However, contrasting results were found by Goyal et al. who reported improvement in acetylcholine-induced endothelium relaxation on administration of exendin- 4 in rat model of T2DM [90]. This effect was abolished by an inhibitor of NOS, suggesting the activation of eNOS by exendin-4 [90]. These results were again contradicted by Murthy et al. who found no significant changes in eNOS and NFkappaB-p65 expression in exenatide treated non-diabetic rats [91]. However, a more recent study conducted by Ding et al. on human umbilical vein endothelial cells (HUVEC) has demonstrated upregulation of eNOS expression via GLP-1R dependent pathways [92].

GLP-1 and its analogs have also been found to inhibit cellular migration and other essential facets of inflammation, thus mitigating atherosclerosis. Nagashima et al. observed inhibition of macrophage foam cell formation by both GLP-1 and GIP, followed by cAMP activation [93]. These effects were found to be associated with downregulation of CD36 and ACAT-1 [93]. Similarly, 
exendin-4 was demonstrated to inhibit inflammatory response in macrophages by Arakawa et al. [94]. Shiraishi and colleagues demonstrated upregulation of alternatively activated macrophage-related molecules, such as IL-10, CD163, and CD204 in human monocyte-derived macrophage by GLP-1 [95]. GLP-1 also activated STAT3 in a GLP-1R dependent manner [95]. GLP-1 also exerts influence on inflammatory mediators. For example, Liu et al. demonstrated inhibition of TNF- $\alpha$ mediated PAI-1 induction, ICAM-1 and VCAM-1 expression by liraglutide in HUVEC [96]. However, a recent study by Panjwani et al. has provided contradictory results. Taspoglutide (a long acting GLP-1 agonist) was not found to have significant anti-atheromatous effects, although it did reduce hepatic triglyceride levels, suggesting an indirect mode of action [97]. DPP-4 inhibitors have also been shown to have anti-inflammatory actions. Recent studies have demonstrated direct suppression of aortic atherosclerosis by both PKF275-055 and sitagliptin [98-100].

GLP-1 has been shown to confer protective effects on the endothelium and to maintain its integrity. For example, Oeseberg showed that dipeptidyl-peptidase 4 (DPP-4) inhibition significantly reduced vascular senescence in a diabetic rat model. This effect was mediated via activation of cAMP response element-binding transcription factor in a cAMP/PKA-dependent manner and induction of oxidative defense genes HO-1 and NQO1 [101]. Similarly, Goto showed that exendin-4 reduced intimal thickening after vascular injury by the suppression of platelet-derived growth factor-induced proliferation in isolated murine, rat and human aortic vascular smooth muscle cells [102]. In vitro studies in HUVECs have further demonstrated these effects. In a study by Ishibashi et al., GLP-1 was shown to dose-dependently inhibit gene expression for advanced glycation end products receptor (RAGE) in HUVEC via activation of cyclic AMP pathways and decrease reactive oxygen species generation [103]. This effect was directly mediated via the GLP-1R [103]. In another study, liraglutide was shown to prevent the onset of endoplasmic reticulum stress in HUVECs exposed to high glucose via dose dependent induction of mitochondrial fusion marker, OPA1, thereby inhibiting mitochondrial fragmentation and apoptosis [104]. Liu and colleagues showed that GLP-1 suppressed the oxidized low-density-lipoproteininduced apoptosis of MILE SVEN 1 cells by inactivating the PARP-1/iNOS/NO pathway [105]. This effect was accompanied by a significant decrease in intracellular nitric oxide activity, suppression of lipid peroxidation and restoration of the activities of endogenous antioxidants [105]. Ergogdu showed that incubation of human coronary artery endothelial cells (HCAECs) with exendin-4 caused an increase in DNA synthesis and cell proliferation through PKA-PI3K/Akt-eNOS activation pathways via a GLP-1 receptor-dependent mechanism [106]. Another paper by the same group showed that incubation of HCAECs with exendin- 4 resulted in a dosedependent up-regulation of DNA synthesis which was associated with enhanced eNOS and Akt expression [106]. This effect was inhibited by PKA, PI3K, Akt or eNOS inhibitors and abolished by a GLP-1 receptor antagonist. Human studies have also demonstrated beneficial effects. For example, Ceriello et al. reported that during the meal, GLP-1 exerted simultaneous effects on insulin secretion and endothelial protection, in a manner dependent on the level of glycemia [107]. Additional data show that liraglutide reduces several markers of cardiovascular risk, such as body weight, A1C levels, Systolic BP, C-reactive protein, type 2 natriuretic peptide, and PAI-1 [108,109]. Exenatide has also exhibited similar effects, with efficacy comparable to that of metformin [110].

\section{Regulation of vasomotor functions and arterial blood pressure}

GLP-1 has been demonstrated to modulate peripheral arterial blood flow by exerting direct effects or via signals from the CNS. Richter showed that addition of GLP-1 caused increase in 35S-sulfate-labeled macromolecule secretion and relaxation of the pulmonary artery [111]. He concluded that GLP-1 may act as neurotransmitter of the peptidergic nervous system in airways [111]. Similarly, Golpon also showed the role of GLP-1 in the modulation of pulmonary vascular tone [112]. Nystrom and colleagues showed dose-dependent relaxation of femoral artery rings by GLP-1 in a rat organ bath model [113]. This effect was shown to be independent of $\mathrm{NO}$ and the endothelium [113]. In contrast, Dong et al. concluded that GLP-1 had a role in expanding microvascular volume via a PKA/NOdependent pathway in the vascular endothelium [114]. In another study, GLP-1 and exendin-4 treatment was shown to normalize the altered vascular tone in type 2 diabetic rats, with the latter being less effective [115]. In a study published in 2012, Wu hypothesized that the vascular modulatory effect on pancreatic islet microcirculation may in fact be one of the mechanisms for anti-diabetic actions of GLP-1 and exendin-4. She showed that infusion of both GLP-1 and exendin-4 prevented glucose-induced pancreatic blood flow redistribution into the islets, an effect that was not abolished by blocking NO formation [116]. Human studies have also pointed towards amelioration of endothelial dysfunction and modulation of vascular reactivity [117]. In the study conducted by Nystrom, GLP-1 was found to be associated with improvement in endothelial dysfunction without improvements in insulin resistance in T2DM patients with coronary heart disease [118]. Due to the direct and indirect role of GLP-1 on endothelial functions, GLP-1 receptor antagonists may 
also serve as potential prospects in addressing cardiovascular risks in T2DM patients [119].

GLP-1 has also been shown to regulate peripheral arterial blood flow via signals from the CNS $[33,120]$. For example, in 2004, Cabou et al. demonstrated that central GLP-1 signaling plays an essential role in the regulation of arterial blood flow, heart rate, and insulin sensitivity [121]. This study was further reinforced by another one in 2011, whereby brain GLP-1 signaling was shown to activate hypothalamic glucose-dependent $\mathrm{PKC}-\delta$ to regulate femoral artery blood flow and insulin sensitivity [122]. Similarly, Isbil-Buyukcoskun and colleagues showed that intracerebroventricularly injected GLP-1 had a role in increasing blood pressure and heart rate [123]. The former was mediated by stimulation of central nicotinic and partially muscarinic receptors and vasopressinergic system, while the latter was mediated by stimulation of central nicotinic receptors [123].

GLP-1 and its analogs also have potent effects on blood pressure, and may therefore play a role in ameliorating hypertension. Previously published data has demonstrated the GLP-1 analogs to have a direct natriuretic effect and a direct mode of action on endothelial vasodilatation $[124,125]$. The mechanisms for GLP-1 mediated diuresis and natriuresis were explained by Crajoinas et al., who reported that these effects were mediated by changes in renal hemodynamics and by downregulation of NHE3 activity in the renal proximal tubule [126]. Recombinant GLP-1 was shown by Yu et al. to have an antihypertensive effect in Dahl Sensitive rats fed with a high salt diet, in addition to cardioprotective and renoprotective effects [127]. The antihypertensive effect is due to its diuretic and natriuretic actions, rather than amelioration of insulin resistance [127]. Exendin-4 also has antihypertensive effects in salt-sensitive mice models. Hirata and colleagues demonstrated that exendin-4 attenuated high-salt load induced hypertension, prevented angiotensin II induced hypertension and inhibited angiotensin II-induced phosphorylation of ERK1/2 [128]. Exenatide has also been shown to have an antihypertensive effect in glucocorticoid-induced model of the metabolic syndrome [129]. This effect occurred independently of changes in body weight [129]. DPP-4 inhibitors have also been demonstrated to have an antihypertensive effect. For example, Sitagliptin was shown to increase GLP-1 and GLP-1 receptor expression in spontaneously hypertensive rat renal arteries by Liu [130]. This upregulation was associated with improvement of endothelial function via restoration of NO bioavailability [130]. This effect was further shown to be partially due to inhibition of NHE3 activity in renal proximal tubule [131].

GLP-1 and its analogs have also been demonstrated to have antihypertensive effects in human studies. For example, exenatide intake was associated with weight loss and reduction in levels of HbA1c, systolic blood pressure, triglycerides, and high-sensitivity CRP in obese patients with type 2 diabetes on insulin [132]. The effect on systolic blood pressure was further confirmed by a pooled analysis of 2171 patients [133]. Liraglutide, longacting GLP-1 agonist, has also been shown to induce significant weight loss and reduce SBP in a group of Asian patients [134]. Antihypertensive effects have also been observed for DPP-4 inhibitors. For example, Yanai et al. reported reduction of body weight, HbA1c levels and blood pressure after 6-month treatment with sitagliptin [135]. The antihypertensive effect of sitagliptin was confirmed by Ogawa, who showed that this effect was independent of BMI and blood glucose reduction [136].

\section{Conclusion and future directions}

Recent studies provide potent evidence for the pleiotropic effects of GLP-1 on the cardiovascular system. This review attempts to highlight the direct cardiovascular effects, without going into details of the indirect actions, which have already been thoroughly reviewed in previous papers. Majority of the present GLP-1 based studies employ GLP-1 analogs such as exenatide as their primary drugs, which raises a question for their cardiovascular safety and contribution to major adverse cardiovascular events (MACE). In an integrated analysis of 3,945 participants, Ratner et al. observed no increase in cardiovascular risk with the use of exenatide BID in patients with type 2 diabetes [137]. Similarly, liraglutide has not been found to be associated with an increase in MACE in FDA's review as well as in a pooled analysis of phase 2 and 3 clinical trials $[138,139]$. Its safety has been confirmed by a recent study published in Lancet, whereby liraglutide had an efficacy comparable to that of glimepiride, but was associated with fewer cardiovascular events [140]. DPP-4 inhibitors also have a favorable cardiovascular safety profile [141]. However, the recently concluded SAVOR-TIMI 53 trial conducted on patients with T2DM with either a history of established CVD or multiple CVD risk factors, has failed to demonstrate the superiority of saxagliptin over placebo in reducing a composite end point of cardiovascular death, nonfatal MI or nonfatal ischemic stroke when added to usual care $[142,143]$. Nevertheless, the relatively low occurrence of MACE implies that the translation of ongoing research to the bedside would provide a safe therapeutic alternative to available anti-diabetics, with additional cardioprotective and vasculoprotective effects.

It is important to note that the dividing line between direct and indirect effects is tenuous and somewhat vague. Its fragility is reinforced by the relative scarcity of existing data that provides conclusive evidence for delineating the two. This notion implies the need for 
additional preclinical and clinical studies that are focused primarily on distinguishing these two entities. These studies will not only provide therapeutic benefits to T2DM patients with superimposed CVDs, but may also unveil new horizons in cardiovascular research. A search at http://www.clinicaltrials.gov (using keywords GLP-1 and cardiovascular) returns 36 open studies, which hints towards an increasing interest in the cardiovascular effects of incretin based therapies.

\section{Competing interests}

The author declares that he has no competing interests.

Received: 17 June 2013 Accepted: 28 August 2013

Published: 29 August 2013

\section{References}

1. WHO | Cardiovascular diseases (CVDs). http://www.who.int/mediacentre/ factsheets/fs317/en/index.html.

2. Heidenreich PA, Trogdon JG, Khavjou OA, Butler J, Dracup K, Ezekowitz MD, Finkelstein EA, Hong $Y$, Johnston SC, Khera A: Forecasting the future of cardiovascular disease in the United States a policy statement from the American heart association. Circulation 2011, 123(8):933-944.

3. Grundy SM, Benjamin IJ, Burke GL, Chait A, Eckel RH, Howard BV, Mitch W, Smith SC Jr, Sowers JR: Diabetes and cardiovascular disease: a statement for healthcare professionals from the American Heart Association. Circulation 1999, 100(10):1134-1146.

4. Lind M, Garcia-Rodriguez LA, Booth GL, Cea-Soriano L, Shah BR, Ekeroth G, Lipscombe LL: Mortality trends in patients with and without diabetes in Ontario, Canada and the UK from 1996 to 2009: a population-based study. Diabetologia 2013. in press.

5. Action to Control Cardiovascular Risk in Diabetes (ACCORD). http://clinicaltrials.gov/ct2/show/NCT00000620.

6. Gerstein HC, Miller ME, Byington RP, Goff DC Jr, Bigger JT, Buse JB, Cushman WC, Genuth S, Ismail-Beigi F, Grimm RH Jr, et al: Effects of intensive glucose lowering in type 2 diabetes. The New England journal of medicine 2008, 358(24):2545-2559.

7. Buglioni A, Burnett JC Jr: A gut-heart connection in cardiometabolic regulation. Nature medicine 2013, 19(5):534-536.

8. Elrick H, Stimmler L, Hlad C, Arai Y: Plasma insulin response to oral and intravenous glucose administration. Journal of Clinical Endocrinology \& Metabolism 1964, 24(10):1076-1082.

9. McIntyre N, Holdsworth CD, Turner DS: Intestinal factors in the control of insulin secretion. The Journal of clinical endocrinology and metabolism 1965, 25(10):1317-1324.

10. Mudaliar S, Henry RR: Incretin therapies: effects beyond glycemic control. The American journal of medicine 2009, 122(6):S25-S36.

11. Haseeb A: Multidimensional effects of glucagon-like peptide-1. El Mednifico Journal 2013, 1(1):3.

12. Miyawaki K, Yamada Y, Ban N, Ihara Y, Tsukiyama K, Zhou H, Fujimoto S, Oku A, Tsuda K, Toyokuni S, et al: Inhibition of gastric inhibitory polypeptide signaling prevents obesity. Nature medicine 2002, 8(7):738-742.

13. Kulkarni RN: GIP: no longer the neglected incretin twin? Science translational medicine 2010, 2(49):49ps47.

14. Kreymann B, Ghatei M, Williams G, Bloom S: Glucagon-like peptide-1 7-36: a physiological incretin in man. Lancet 1987, 330(8571):1300-1304.

15. Deacon CF: Circulation and degradation of GIP and GLP-1. Hormone and metabolic research $=$ Hormon- und Stoffwechselforschung $=$ Hormones et metabolisme 2004, 36(11-12):761-765.

16. Asmar M, Simonsen L, Madsbad S, Stallknecht B, Holst JJ, Bülow J: GIP may enhance fatty acid re-esterification in subcutaneous, abdominal adipose tissue in lean humans. Diabetes 2010, 59(9):2160-2163.

17. Meier JJ, Gallwitz B, Siepmann N, Holst JJ, Deacon CF, Schmidt WE, Nauck MA: Gastric inhibitory polypeptide (GIP) dose-dependently stimulates glucagon secretion in healthy human subjects at euglycaemia. Diabetologia 2003, 46(6):798-801.
18. Chia CW, Carlson OD, Kim W, Shin YK, Charles CP, Kim HS, Melvin DL, Egan JM: Exogenous glucose-dependent insulinotropic polypeptide worsens post prandial hyperglycemia in type 2 diabetes. Diabetes 2009, 58(6):1342-1349.

19. Kieffer TJ, Habener JF: The glucagon-like peptides. Endocrine reviews 1999 20(6):876-913

20. Seino Y, Fukushima M, Yabe D: GIP and GLP-1, the two incretin hormones: Similarities and differences. Journal of Diabetes Investigation 2010 1(1-2):8-23.

21. Mayo KE, Miller LJ, Bataille D, Dalle S, Göke B, Thorens B, Drucker DJ: International Union of Pharmacology. XXXV. The glucagon receptor family. Pharmacological reviews 2003, 55(1):167-194.

22. McClean PL, Parthsarathy $V$, Faivre $E$, Holscher $C$ : The diabetes drug liraglutide prevents degenerative processes in a mouse model of Alzheimer's disease. The Journal of neuroscience: the official journal of the Society for Neuroscience 2011, 31(17):6587-6594.

23. Porter DW, Irwin N, Flatt PR, Hölscher C, Gault VA: Prolonged GIP receptor activation improves cognitive function, hippocampal synaptic plasticity and glucose homeostasis in high-fat fed mice. European journal of pharmacology 2011, 650(2):688-693.

24. Paratore S, Ciotti MT, Basille M, Vaudry D, Gentile A, Parenti R, Calissano P, Cavallaro S: Gastric inhibitory polypeptide and its receptor are expressed in the central nervous system and support neuronal survival. Central nervous system agents in medicinal chemistry 2011, 11(3):210-222.

25. Verspohl EJ: Novel therapeutics for type 2 diabetes: Incretin hormone mimetics (glucagon-like peptide-1 receptor agonists) and dipeptidyl peptidase-4 inhibitors. Pharmacol Ther 2009, 124(1):113-138.

26. Lovshin JA, Drucker DJ: Incretin-based therapies for type 2 diabetes mellitus. Nat Rev Endocrinol 2009, 5(5):262-269.

27. Fadini GP, Avogaro A: Cardiovascular effects of DPP-4 inhibition: Beyond GLP-1. Vascul Pharmacol 2011, 55(1-3):10-16.

28. Wei $Y$, Mojsov S: Tissue-specific expression of the human receptor for glucagon-like peptide-l: brain, heart and pancreatic forms have the same deduced amino acid sequences. FEBS letters 1995, 358(3):219-224.

29. Bullock BP, Heller RS, Habener JF: Tissue distribution of messenger ribonucleic acid encoding the rat glucagon-like peptide-1 receptor. Endocrinology 1996, 137(7):2968-2978

30. Green BD, Hand KV, Dougan JE, McDonnell BM, Cassidy RS, Grieve DJ: GLP-1 and related peptides cause concentration-dependent relaxation of rat aorta through a pathway involving KATP and CAMP. Archives of biochemistry and biophysics 2008, 478(2):136-142.

31. Ban K, Noyan-Ashraf MH, Hoefer J, Bolz SS, Drucker DJ, Husain M: Cardioprotective and vasodilatory actions of glucagon-like peptide 1 receptor are mediated through both glucagon-like peptide 1 receptor-dependent and-independent pathways. Circulation 2008, 117(18):2340-2350.

32. Barragan JM, Rodriguez RE, Blazquez E: Changes in arterial blood pressure and heart rate induced by glucagon-like peptide-1-(7-36) amide in rats The American journal of physiology 1994, 266(3 Pt 1):E459-E466.

33. Yamamoto H, Lee CE, Marcus JN, Williams TD, Overton JM, Lopez ME, Hollenberg AN, Baggio L, Saper CB, Drucker DJ, et al: Glucagon-like peptide-1 receptor stimulation increases blood pressure and heart rate and activates autonomic regulatory neurons. The Journal of clinical investigation 2002, 110(1):43-52.

34. Ahren B: GLP-1 and extra-islet effects. Hormone and metabolic research $=$ Hormon- und Stoffwechselforschung $=$ Hormones et metabolisme 2004, 36(11-12):842-845.

35. Gros R, You X, Baggio LL, Kabir MG, Mungrue IN, Parker TG, Huang Q, Drucker DJ, Husain M: Cardiac function in mice lacking the glucagon-like peptide-1 receptor. Endocrinology 2003, 144(6):2242-2252.

36. Deacon CF, Pridal L, Klarskov L, Olesen M, Holst JJ: Glucagon-like peptide 1 undergoes differential tissue-specific metabolism in the anesthetized pig. American Journal of Physiology - Endocrinology And Metabolism 1996 271(3):E458-E464.

37. Vila Petroff MG, Egan JM, Wang X, Sollott SJ: Glucagon-like peptide-1 increases CAMP but fails to augment contraction in adult rat cardiac myocytes. Circulation research 2001, 89(5):445-452.

38. Ban K, Kim KH, Cho CK, Sauve M, Diamandis EP, Backx PH, Drucker DJ, Husain M: Glucagon-like peptide (GLP)-1(9-36)amide-mediated cytoprotection is blocked by exendin(9-39) yet does not require the known GLP-1 receptor. Endocrinology 2010, 151(4):1520-1531. 
39. Gill A, Hoogwerf B, Burger J, Bruce S, MacConell L, Yan P, Braun D, Giaconia J, Malone J: Effect of exenatide on heart rate and blood pressure in subjects with type 2 diabetes mellitus: a double-blind, placebo-controlled, randomized pilot study. Cardiovasc Diabetol 2010, 9(1):6

40. Chatterjee DJ, Khutoryansky N, Zdravkovic M, Sprenger CR, Litwin JS: Absence of QTc prolongation in a thorough QT study with subcutaneous liraglutide, a once-daily human GLP-1 analog for treatment of type 2 diabetes. J Clin Pharmacol 2009, 49(11):1353-1362.

41. Bloomfield DM, Krishna R, Hreniuk D, Hickey L, Ghosh K, Bergman AJ, Miller J, Gutierrez MJ, Stoltz R, Gottesdiener KM, et al: A thorough QTc study to assess the effect of sitagliptin, a DPP4 inhibitor, on ventricular repolarization in healthy subjects. Journal of clinical pharmacology 2009, 49(8):937-946

42. He YL, Zhang Y, Serra D, Wang Y, Ligueros-Saylan M, Dole WP: Thorough QT study of the effects of vildagliptin, a dipeptidyl peptidase IV inhibitor, on cardiac repolarization and conduction in healthy volunteers. Current medical research and opinion 2011, 27(7):1453-1463.

43. Dokken BB, Hilwig WR, Teachey MK, Panchal RA, Hubner K, Allen D, Rogers DC, Kern KB: Glucagon-like peptide-1 (GLP-1) attenuates post-resuscitation myocardial microcirculatory dysfunction. Resuscitation 2010, 81(6):755-760

44. Dokken BB, Piermarini CV, Teachey MK, Gura MT, Dameff CJ, Heller BD, Krate J, Ashgar AM, Querin L, Mitchell JL, et al: Glucagon-like peptide-1 preserves coronary microvascular endothelial function after cardiac arrest and resuscitation: Potential anti-oxidant effects. American journal of physiology Heart and circulatory physiology 2012, 304(4):H538-546.

45. Sokos GG, Bolukoglu H, German J, Hentosz T, Magovern GJ Jr, Maher TD, Dean DA, Bailey SH, Marrone G, Benckart DH, et al: Effect of glucagon-like peptide-1 (GLP-1) on glycemic control and left ventricular function in patients undergoing coronary artery bypass grafting. The American journal of cardiology 2007, 100(5):824-829.

46. Patent US7790681 - Treatment of cardiac arrhythmias with GLP-1 receptor ligands. http://www.google.com/patents/US7790681.

47. Taegtmeyer $\mathrm{H}$ : Cardiac metabolism as a target for the treatment of heart failure. Circulation 2004, 110(8):894-896.

48. van der Vusse GJ, van Bilsen M, Glatz JF: Cardiac fatty acid uptake and transport in health and disease. Cardiovascular research 2000, 45(2):279-293.

49. Noyan-Ashraf MH, Shikatani EA, Schuiki I, Mukovozov I, Wu J, Li RK, Volchuk A, Robinson LA, Billia F, Drucker DJ, et al: A glucagon-like Peptide-1 analog reverses the molecular pathology and cardiac dysfunction of a mouse model of obesity. Circulation 2013, 127(1):74-85.

50. Nikolaidis LA, Elahi D, Hentosz T, Doverspike A, Huerbin R, Zourelias L, Stolarski C, Shen YT, Shannon RP: Recombinant glucagon-like peptide-1 increases myocardial glucose uptake and improves left ventricular performance in conscious dogs with pacing-induced dilated cardiomyopathy. Circulation 2004, 110(8):955-961.

51. Villanueva-Penacarrillo ML, Puente J, Redondo A, Clemente F, Valverde I: Effect of GLP-1 treatment on GLUT2 and GLUT4 expression in type 1 and type 2 rat diabetic models. Endocrine 2001, 15(2):241-248.

52. Vyas AK, Yang KC, Woo D, Tzekov A, Kovacs A, Jay PY, Hruz PW: Exenatide improves glucose homeostasis and prolongs survival in a murine mode of dilated cardiomyopathy. PloS one 2011, 6(2):e17178.

53. Kavianipour M, Ehlers MR, Malmberg K, Ronquist G, Ryden L, Wikstrom G, Gutniak M: Glucagon-like peptide-1 (7-36) amide prevents the accumulation of pyruvate and lactate in the ischemic and non-ischemic porcine myocardium. Peptides 2003, 24(4):569-578.

54. Portha B, Tourrel-Cuzin C, Movassat J: Activation of the GLP-1 receptor signalling pathway: a relevant strategy to repair a deficient beta-cell mass. Experimental diabetes research 2011, 2011:376509.

55. Bose AK, Mocanu MM, Carr RD, Brand CL, Yellon DM: Glucagon-like Peptide 1 Can Directly Protect the Heart Against Ischemia/Reperfusion Injury. Diabetes 2005, 54(1):146-151.

56. Noyan-Ashraf MH, Momen MA, Ban K, Sadi AM, Zhou YQ, Riazi AM, Baggio LL, Henkelman RM, Husain M, Drucker DJ: GLP-1R agonist liraglutide activates cytoprotective pathways and improves outcomes after experimental myocardial infarction in mice. Diabetes 2009, 58(4):975-983
57. Sonne DP, Engstrom T, Treiman M: Protective effects of GLP-1 analogues exendin-4 and GLP-1(9-36) amide against ischemia-reperfusion injury in rat heart. Regulatory peptides 2008, 146(1-3):243-249.

58. Timmers L, Henriques JP, de Kleijn DP, Devries JH, Kemperman $H$, Steendijk P, Verlaan CW, Kerver M, Piek JJ, Doevendans PA, et al: Exenatide reduces infarct size and improves cardiac function in a porcine model of ischemia and reperfusion injury. J Am Coll Cardiol 2009, 53(6):501-510.

59. Younce C, Burmeister MA, Ayala JE: Exendin-4 attenuates high glucose-induced cardiomyocyte apoptosis via inhibition of endoplasmic reticulum stress and activation of SERCA2a. American Journal of Physiology - Cell Physiology 2013, 304(6):C508-518.

60. Ye Y, Perez-Polo JR, Aguilar D, Birnbaum $Y$ : The potential effects of anti-diabetic medications on myocardial ischemia-reperfusion injury. Basic research in cardiology 2011, 106(6):925-952.

61. Hausenloy D, Wynne A, Theodorou L, Mocanu M, Yellon D: FC1 Dipeptidyl peptidase IV inhibitors limit myocardial infarct size in a glucose-sensitive manner. Heart 2010, 96(17):e11-e11.

62. Yin M, Sillje HH, Meissner M, van Gilst WH, de Boer RA: Early and late effects of the DPP-4 inhibitor vildagliptin in a rat model of post-myocardial infarction heart failure. Cardiovasc Diabetol 2011, 10:85.

63. Dokken BB, La Bonte LR, Davis-Gorman G, Teachey MK, Seaver N, McDonagh PF: Glucagon-like peptide-1 (GLP-1), immediately prior to reperfusion, decreases neutrophil activation and reduces myocardial infarct size in rodents. Hormone and metabolic research = Hormon- und Stoffwechselforschung = Hormones et metabolisme 2011, 43(5):300-305.

64. Bernink FJ, Timmers L, Diamant M, Scholte M, Beek AM, Kamp O, Marques KM, Denham RN, Chen WJ, Doevendans PA, et al: Effect of additional treatment with EXenatide in patients with an Acute Myocardial Infarction: the EXAMI study. International journal of cardiology 2013, 167(1):289-290.

65. Lonborg J, Vejlstrup N, Kelbaek H, Botker HE, Kim WY, Mathiasen AB, Jorgensen E, Helqvist S, Saunamaki K, Clemmensen P, et al: Exenatide reduces reperfusion injury in patients with ST-segment elevation myocardial infarction. European heart journal 2012, 33(12):1491-1499.

66. Nikolaidis LA, Mankad S, Sokos GG, Miske G, Shah A, Elahi D, Shannon RP: Effects of Glucagon-Like Peptide-1 in Patients With Acute Myocardial Infarction and Left Ventricular Dysfunction After Successful Reperfusion. Circulation 2004, 109(8):962-965.

67. Read PA, Khan FZ, Dutka DP: Cardioprotection against ischaemia induced by dobutamine stress using glucagon-like peptide- 1 in patients with coronary artery disease. Heart 2012, 98(5):408-413.

68. Read PA, Hoole SP, White PA, Khan FZ, O'Sullivan M, West NE, Dutka DP: A pilot study to assess whether glucagon-like peptide- 1 protects the heart from ischemic dysfunction and attenuates stunning after coronary balloon occlusion in humans. Circulation Cardiovascular interventions 2011 4(3):266-272.

69. Best JH, Hoogwerf BJ, Herman WH, Pelletier EM, Smith DB, Wenten M Hussein MA: Risk of cardiovascular disease events in patients with type 2 diabetes prescribed the glucagon-like peptide 1 (GLP-1) receptor agonist exenatide twice daily or other glucose-lowering therapies: a retrospective analysis of the LifeLink database. Diabetes care 2011 34(1):90-95

70. Read PA, Khan FZ, Heck PM, Hoole SP, Dutka DP: DPP-4 Inhibition by Sitagliptin Improves the Myocardial Response to Dobutamine Stress and Mitigates Stunning in a Pilot Study of Patients With Coronary Artery Disease / CLINICAL PERSPECTIVE. Circ Cardiovasc Imaging 2010, 3(2):195-201.

71. Theiss HD, Brenner C, Engelmann MG, Zaruba MM, Huber B Henschel V, Mansmann U, Wintersperger B, Reiser M, Steinbeck G, et al: Safety and efficacy of SITAgliptin plus GRanulocyte-colony-stimulating factor in patients suffering from Acute Myocardial Infarction (SITAGRAMI-Trial)-rationale, design and first interim analysis. International journal of cardiology 2010, 145(2):282-284.

72. Ingelsson E, Sundström J, Ärnlöv J, Zethelius B, Lind L: Insulin resistance and risk of congestive heart failure. JAMA: the journal of the American Medical Association 2005, 294(3):334-341.

73. Bhashyam S, Fields AV, Patterson B, Testani JM, Chen L, Shen Y-t, Shannon RP: Glucagon-like peptide- 1 increases myocardial glucose uptake via p38a MAP kinase-mediated, nitric oxide-dependent mechanisms in conscious dogs with dilated cardiomyopathy/clinical perspective. Circ Heart Fail 2010, 3(4):512-521. 
74. Poornima I, Brown SB, Bhashyam S, Parikh P, Bolukoglu H, Shannon RP: Chronic glucagon-like peptide-1 infusion sustains left ventricular systolic function and prolongs survival in the spontaneously hypertensive, heart failure-prone rat. Circulation Heart failure 2008, 1(3):153-160.

75. Liu Q, Anderson C, Broyde A, Polizzi C, Fernandez R, Baron A, Parkes D: Glucagon-like peptide-1 and the exenatide analogue AC3174 improve cardiac function, cardiac remodeling, and survival in rats with chronic heart failure. Cardiovasc Diabetol 2010, 9(1):76.

76. Shigeta T, Aoyama M, Bando YK, Monji A, Mitsui T, Takatsu M, Cheng XW, Okumura T, Hirashiki A, Nagata K, et al: Dipeptidyl peptidase-4 modulates left ventricular dysfunction in chronic heart failure via angiogenesis-dependent and -independent actions. Circulation 2012, 126(15):1838-1851.

77. Gomez N, Touihri K, Matheeussen V, Mendes Da Costa A Mahmoudabady M, Mathieu M, Baerts L, Peace A, Lybaert P, Scharpe S, et al: Dipeptidyl peptidase IV inhibition improves cardiorenal function in overpacing-induced heart failure. European journal of heart failure 2012, 14(1):14-21.

78. Thrainsdottir I, Malmberg K, Olsson A, Gutniak M, Ryden L: Initial experience with GLP-1 treatment on metabolic control and myocardial function in patients with type 2 diabetes mellitus and heart failure. Diabetes \& vascular disease research : official journal of the International Society of Diabetes and Vascular Disease 2004, 1(1):40-43.

79. Sokos GG, Nikolaidis LA, Mankad S, Elahi D, Shannon RP: Glucagon-like peptide-1 infusion improves left ventricular ejection fraction and functional status in patients with chronic heart failure. Journal of cardiac failure 2006, 12(9):694-699.

80. Halbirk M, Nørrelund H, Møller N, Holst JJ, Schmitz O, Nielsen R, Nielsen-Kudsk JE, Nielsen SS, Nielsen TT, Eiskjær H, et al: Cardiovascular and metabolic effects of 48-h glucagon-like peptide-1 infusion in compensated chronic patients with heart failure. Am J Physiol Heart Circ Physiol 2010, 298(3):H1096-H1102.

81. Nathanson D, Ullman B, Lofstrom U, Hedman A, Frick M, Sjoholm A, Nystrom T: Effects of intravenous exenatide in type 2 diabetic patients with congestive heart failure: a double-blind, randomised controlled clinical trial of efficacy and safety. Diabetologia 2012, 55(4):926-935

82. Munaf M, Pellicori P, Allgar V, Wong K: A meta-analysis of the therapeutic effects of glucagon-like Peptide-1 agonist in heart failure. International journal of peptides 2012, 2012:249827.

83. Félétou M, Vanhoutte PM: Endothelium-derived hyperpolarizing factor where are we now? Arteriosclerosis, thrombosis, and vascular biology 2006, 26(6):1215-1225.

84. Funk SD, Yurdagul A, Orr AW: Hyperglycemia and endothelial dysfunction in Atherosclerosis: lessons from type 1 diabetes. International Journal of Vascular Medicine 2012, 2012:569654.

85. Chalmers J, MacMahon S, Patel A, Cooper M, Ferrannini E, Glasziou P, Grobbee D, Hamet P, Harrap S, Heller S: Intensive blood glucose control and vascular outcomes in patients with type 2 diabetes. The New England journal of medicine 2008, 358(24):2560-2572.

86. Duckworth W, Abraira C, Moritz T, Reda D, Emanuele N, Reaven P, Zieve F, Marks J, Davis S, Hayward R, et al: Glucose control and vascular complications in veterans with type 2 diabetes. New Engl J Med 2009, 360:129-139.

87. Caballero AE: Endothelial dysfunction in obesity and insulin resistance: a road to diabetes and heart disease. Obesity research 2003 11(11):1278-1289.

88. Davignon J, Ganz P: Role of endothelial dysfunction in Atherosclerosis Circulation 2004, 109(23 suppl 1):III-27-|II-32.

89. Nathanson D, Erdogdu O, Pernow J, Zhang Q, Nystrom T: Endothelial dysfunction induced by triglycerides is not restored by exenatide in rat conduit arteries ex vivo. Regulatory peptides 2009, 157(1-3):8-13.

90. Goyal S, Kumar S, Bijjem KV, Singh M: Role of glucagon-like peptide- 1 in vascular endothelial dysfunction. Indian journal of experimental biology 2010, 48(1):61-69.

91. Murthy SN, Hilaire RC, Casey DB, Badejo AM, McGee J, McNamara DB, Kadowitz PJ, Fonseca VA: The synthetic GLP-I receptor agonist, exenatide, reduces intimal hyperplasia in insulin resistant rats. Diabetes \& vascular disease research : official journal of the International Society of Diabetes and Vascular Disease 2010, 7(2):138-144.
92. Ding L, Zhang J: Glucagon-like peptide-1 activates endothelial nitric oxide synthase in human umbilical vein endothelial cells. Acta pharmacologica Sinica 2012, 33(1):75-81.

93. Nagashima M, Watanabe T, Terasaki M, Tomoyasu M, Nohtomi K, Kim-Kaneyama J, Miyazaki A, Hirano T: Native incretins prevent the development of atherosclerotic lesions in apolipoprotein $\mathrm{E}$ knockout mice. Diabetologia 2011, 54(10):2649-2659.

94. Arakawa M, Mita T, Azuma K, Ebato C, Goto H, Nomiyama T, Fujitani Y, Hirose T, Kawamori R, Watada H: Inhibition of monocyte adhesion to endothelial cells and attenuation of atherosclerotic lesion by a glucagon-like peptide-1 receptor agonist, exendin-4. Diabetes 2010, 59(4):1030-1037

95. Shiraishi D, Fujiwara Y, Komohara Y, Mizuta H, Takeya M: Glucagon-like peptide-1 (GLP-1) induces M2 polarization of human macrophages via STAT3 activation. Biochemical and biophysical research communications 2012, 425(2):304-308.

96. Liu $H$, Dear AE, Knudsen LB, Simpson RW: A long-acting glucagon-like peptide- 1 analogue attenuates induction of plasminogen activator inhibitor type-1 and vascular adhesion molecules. The Journal of endocrinology 2009, 201(1):59-66.

97. Panjwani N, Mulvihill EE, Lonquet C, Yusta B, Campbell JE, Brown TJ, Streutker C, Holland D, Cao X, Baggio LL, et al: GLP-1 Receptor Activation Indirectly Reduces Hepatic Lipid Accumulation But Does Not Attenuate Development of Atherosclerosis in Diabetic Male ApoE-/- Mice. Endocrinology 2013, 154(1):127-139.

98. Terasaki M, Nagashima M, Watanabe T, Nohtomi K, Mori Y, Miyazaki A, Hirano T: Effects of PKF275-055, a dipeptidyl peptidase-4 inhibitor, on the development of atherosclerotic lesions in apolipoprotein E-null mice. Metabolism: clinical and experimental 2012, 61(7):974-977.

99. Vittone F, Liberman A, Vasic D, Ostertag R, Esser M, Walcher D, Ludwig A Marx N, Burgmaier M: Sitagliptin reduces plaque macrophage content and stabilises arteriosclerotic lesions in Apoe (-/-) mice. Diabetologia 2012, 55(8):2267-2275.

100. Makdissi A, Ghanim H, Vora M, Green K, Abuaysheh S, Chaudhuri A, Dhindsa S, Dandona P: Sitagliptin exerts an antinflammatory action. The Journal of clinical endocrinology and metabolism 2012, 97(9):3333-3341.

101. Oeseburg $H$, de Boer RA, Buikema $H$, van der Harst $P$, van Gilst WH, Sillje $\mathrm{HH}$ : Glucagon-like peptide 1 prevents reactive oxygen species-induced endothelial cell senescence through the activation of protein kinase $A$. Arteriosclerosis, thrombosis, and vascular biology 2010, 30(7):1407-1414.

102. Goto H, Nomiyama T, Mita T, Yasunari E, Azuma K, Komiya K, Arakawa M, Jin WL, Kanazawa A, Kawamori R, et al: Exendin-4, a glucagon-like peptide-1 receptor agonist, reduces intimal thickening after vascular injury. Biochemical and biophysical research communications 2011, 405(1):79-84.

103. Ishibashi Y, Matsui T, Takeuchi M, Yamagishi S: Glucagon-like peptide-1 (GLP-1) inhibits advanced glycation end product (AGE)-induced up-regulation of VCAM-1 mRNA levels in endothelial cells by suppressing AGE receptor (RAGE) expression. Biochemical and biophysical research communications 2010, 391(3):1405-1408.

104. Schisano B, Harte AL, Lois K, Saravanan P, Al-Daghri N, Al-Attas O, Knudsen LB, McTernan PG, Ceriello A, Tripathi G: GLP-1 analogue, Liraglutide protects human umbilical vein endothelial cells against high glucose induced endoplasmic reticulum stress. Regulatory peptides 2012, 174(1-3):46-52.

105. Liu FQ, Zhang XL, Gong L, Wang XP, Wang J, Hou XG, Sun Y, Qin WD, Wei SJ, Zhang $Y$, et al: Glucagon-like peptide 1 protects microvascular endothelial cells by inactivating the PARP-1/iNOS/NO pathway. Molecular and cellular endocrinology 2011, 339(1-2):25-33.

106. Erdogdu O, Nathanson D, Sjoholm A, Nystrom T, Zhang Q: Exendin-4 stimulates proliferation of human coronary artery endothelial cells through eNOS-, PKA- and PI3K/Akt-dependent pathways and requires GLP-1 receptor. Molecular and cellular endocrinology 2010, 325(1-2):26-35

107. Ceriello A, Esposito K, Testa R, Bonfigli AR, Marra M, Giugliano D: The possible protective role of glucagon-like peptide 1 on endothelium during the meal and evidence for an "endothelial resistance" to glucagon-like peptide 1 in diabetes. Diabetes care 2011, 34(3):697-702.

108. Courreges JP, Vilsboll T, Zdravkovic M, Le-Thi T, Krarup T, Schmitz O, Verhoeven R, Buganova I, Madsbad S: Beneficial effects of once-daily liraglutide, a human glucagon-like peptide- 1 analogue, on 
cardiovascular risk biomarkers in patients with Type 2 diabetes. Diabetic medicine: a journal of the British Diabetic Association 2008, 25(9):1129-1131.

109. Varanasi A, Patel P, Makdissi A, Dhindsa S, Chaudhuri A, Dandona P: Clinical use of liraglutide in type 2 diabetes and its effects on cardiovascular risk factors. Endocrine practice: official journal of the American College of Endocrinology and the American Association of Clinical Endocrinologists 2012, 18(2):140-145.

110. Kelly AS, Bergenstal RM, Gonzalez-Campoy JM, Katz H, Bank AJ: Effects of exenatide vs. metformin on endothelial function in obese patients with pre-diabetes: a randomized trial. Cardiovasc Diabetol 2012, 11:64

111. Richter G, Feddersen O, Wagner U, Barth P, Goke R, Goke B: GLP-1 stimulates secretion of macromolecules from airways and relaxes pulmonary artery. The American journal of physiology 1993 265(4 Pt 1):L374-L381.

112. Golpon HA, Puechner A, Welte T, Wichert PV, Feddersen CO Vasorelaxant effect of glucagon-like peptide-(7-36)amide and amylin on the pulmonary circulation of the rat. Regulatory peptides 2001, 102(2-3):81-86.

113. Nystrom T, Gonon AT, Sjoholm A, Pernow J: Glucagon-like peptide-1 relaxes rat conduit arteries via an endothelium-independent mechanism. Regulatory peptides 2005, 125(1-3):173-177.

114. Dong Z, Chai W, Wang W, Zhao L, Fu Z, Cao W, Liu Z: Protein kinase $A$ mediates glucagon-like peptide 1-induced nitric oxide production and muscle microvascular recruitment. American journal of physiology Endocrinology and metabolism 2013, 304(2):E222-E228.

115. Ozyazgan S, Kutluata N, Afsar S, Ozdas SB, Akkan AG: Effect of glucagon-like peptide-1(7-36) and exendin-4 on the vascular reactivity in streptozotocin/nicotinamide-induced diabetic rats. Pharmacology 2005, 74(3):119-126.

116. Wu L, Olverling A, Huang $Z$, Jansson L, Chao H, Gao X, Sjoholm A: GLP-1, exendin-4 and C-peptide regulate pancreatic islet microcirculation, insulin secretion and glucose tolerance in rats. Clinical science 2012, 122(8):375-384. London, England: 1979.

117. Tesauro M, Schinzari F, Adamo A, Rovella V, Martini F, Mores N, Barini A, Pitocco D, Ghirlanda G, Lauro D: Effects of GLP-1 on Forearm Vasodilator Function and Glucose Disposal During Hyperinsulinemia in the Metabolic Syndrome. Diabetes care 2012, 36(3):683-689.

118. Nystrom T, Gutniak MK, Zhang Q, Zhang F, Holst JJ, Ahren B, Sjoholm A: Effects of glucagon-like peptide-1 on endothelial function in type 2 diabetes patients with stable coronary artery disease. American journal of physiology Endocrinology and metabolism 2004, 287(6):E1209-E1215.

119. Sjoholm A: Impact of glucagon-like peptide-1 on endothelial function. Diabetes, obesity \& metabolism 2009, 11(Suppl 3):19-25.

120. Yamamoto $H$, Kishi T, Lee CE, Choi BJ, Fang H, Hollenberg AN, Drucker DJ, Elmquist JK: Glucagon-like peptide-1-responsive catecholamine neurons in the area postrema link peripheral glucagon-like peptide-1 with central autonomic control sites. The Journal of neuroscience: the official journal of the Society for Neuroscience 2003, 23(7):2939-2946.

121. Cabou C, Campistron G, Marsollier N, Leloup C, Cruciani-Guglielmacci C, Penicaud L, Drucker DJ, Magnan C, Burcelin R: Brain glucagon-like peptide-1 regulates arterial blood flow, heart rate, and insulin sensitivity. Diabetes 2008, 57(10):2577-2587.

122. Cabou C, Vachoux C, Campistron G, Drucker DJ, Burcelin R: Brain GLP-1 signaling regulates femoral artery blood flow and insulin sensitivity through hypothalamic PKC-delta. Diabetes 2011, 60(9):2245-2256.

123. Isbil-Buyukcoskun N, Gulec G: Effects of intracerebroventricularly injected glucagon-like peptide- 1 on cardiovascular parameters; role of central cholinergic system and vasopressin. Regulatory peptides 2004, 118(1-2):33-38

124. Gutzwiller JP, Tschopp S, Bock A, Zehnder CE, Huber AR, Kreyenbuehl M, Gutmann H, Drewe J, Henzen C, Goeke B, et al: Glucagonlike peptide 1 induces natriuresis in healthy subjects and in insulinresistant obese men. The Journal of clinical endocrinology and metabolism 2004, 89(6):3055-3061.

125. Nystrom T: The potential beneficial role of glucagon-like peptide-1 in endothelial dysfunction and heart failure associated with insulin resistance. Hormone and metabolic research = Hormon- und Stoffwechselforschung = Hormones et metabolisme 2008 2008, 40(9):593-606.

126. Crajoinas RO, Oricchio FT, Pessoa TD, Pacheco BP, Lessa LM, Malnic G, Girardi AC: Mechanisms mediating the diuretic and natriuretic actions of the incretin hormone glucagon-like peptide-1. American journal of physiology Renal physiology 2011, 301(2):F355-F363.

127. Yu M, Moreno C, Hoagland KM, Dahly A, Ditter K, Mistry M, Roman RJ: Antihypertensive effect of glucagon-like peptide 1 in Dahl salt-sensitive rats. Journal of hypertension 2003, 21(6):1125-1135.

128. Hirata K, Kume S, Araki S, Sakaguchi M, Chin-Kanasaki M, Isshiki K, Sugimoto T, Nishiyama A, Koya D, Haneda M, et al: Exendin-4 has an anti-hypertensive effect in salt-sensitive mice model. Biochemical and biophysical research communications 2009, 380(1):44-49.

129. Laugero KD, Stonehouse AH, Guss S, Landry J, Vu C, Parkes DG: Exenatide improves hypertension in a rat model of the metabolic syndrome. Metabolic syndrome and related disorders 2009, 7(4):327-334.

130. Liu L, Liu J, Wong WT, Tian XY, Lau CW, Wang YX, Xu G, Pu Y, Zhu Z, Xu A, et al: Dipeptidyl peptidase 4 inhibitor sitagliptin protects endothelial function in hypertension through a glucagon-like peptide 1-dependent mechanism. Hypertension 2012 60(3):833-841.

131. Pacheco BP, Crajoinas RO, Couto GK, Davel AP, Lessa LM, Rossoni LV, Girardi AC: Dipeptidyl peptidase IV inhibition attenuates blood pressure rising in young spontaneously hypertensive rats. Journal of hypertension 2011, 29(3):520-528

132. Viswanathan $P$, Chaudhuri A, Bhatia R, Al-Atrash F, Mohanty P, Dandona P: Exenatide therapy in obese patients with type 2 diabetes mellitus treated with insulin. Endocrine practice: official journal of the American College of Endocrinology and the American Association of Clinical Endocrinologists 2007, 13(5):444-450.

133. Okerson T, Yan P, Stonehouse A, Brodows R: Effects of exenatide on systolic blood pressure in subjects with type 2 diabetes. American journal of hypertension 2010, 23(3):334-339.

134. Yang W, Chen L, Ji Q, Liu X, Ma J, Tandon N, Bhattacharyya A, Kumar A, Kim KW, Yoon KH, et al: Liraglutide provides similar glycaemic control as glimepiride (both in combination with metformin) and reduces body weight and systolic blood pressure in Asian population with type 2 diabetes from China, South Korea and India: a 16-week, randomized, double-blind, active control trial $\left({ }^{*}\right)$. Diabetes, obesity \& metabolism 2011, 13(1):81-88.

135. Yanai H, Adachi $H$, Hamasaki H, Masui Y, Yoshikawa R, Moriyama S Mishima S, Sako A: Effects of 6-month sitagliptin treatment on glucose and lipid metabolism, blood pressure, body weight and renal function in type 2 diabetic patients: a chart-based analysis. Journal of clinical medicine research 2012, 4(4):251-258.

136. Ogawa S, Ishiki M, Nako K, Okamura M, Senda M, Mori T, Ito S: Sitagliptin, a dipeptidyl peptidase-4 inhibitor, decreases systolic blood pressure in Japanese hypertensive patients with type 2 diabetes. The Tohoku journal of experimental medicine 2011, 223(2):133-135.

137. Ratner R, Han J, Nicewarner D, Yushmanova I, Hoogwerf B, Shen L: Cardiovascular safety of exenatide BID: an integrated analysis from controlled clinical trials in participants with type 2 diabetes. Cardiovasc Diabetol 2011, 10(1):22

138. Parks M, Rosebraugh C: Weighing risks and benefits of liraglutide - the FDA's review of a new antidiabetic therapy. New England Journal of Medicine 2010, 362(9):774-777.

139. Marso SP, Lindsey JB, Stolker JM, House JA, Martinez Ravn G, Kennedy KF, Jensen TM, Buse JB: Cardiovascular safety of liraglutide assessed in a patient-level pooled analysis of phase $2-3$ liraglutide clinical development studies. Diabetes and Vascular Disease Research 2011, 8(3):237-240.

140. Gallwitz B, Rosenstock J, Rauch T, Bhattacharya S, Patel S, von Eynatten M, Dugi KA, Woerle HJ: 2-year efficacy and safety of linagliptin compared with glimepiride in patients with type 2 diabetes inadequately controlled on metformin: a randomised, double-blind, non-inferiority trial. Lancet 2012, 380(9840):475-483.

141. Patil HR, Al Badarin FJ, Al Shami HA, Bhatti SK, Lavie CJ, Bell DS, O'Keefe JH: Meta-analysis of effect of dipeptidyl peptidase-4 inhibitors on cardiovascular risk in type 2 diabetes mellitus. The American journal of cardiology 2012, 110(6):826-833. 
142. Does Saxagliptin Reduce the Risk of Cardiovascular Events When Used Alone or Added to Other Diabetes Medications (SAVOR- TIMI 53). http://clinicaltrials.gov/ct2/show/NCT01107886.

143. AstraZeneca and Bristol-Myers Squibb Announce Top Line Results for SAVOR-TIMI-53 Cardiovascular Outcomes Trial of Onglyza (saxagliptin). http://news.bms.com/press-release/astrazeneca-and-bristol-myers-squibbannounce-top-line-results-savor-timi-53-cardiovas.

doi:10.1186/1758-5996-5-47

Cite this article as: Sheikh: Direct cardiovascular effects of glucagon like peptide-1. Diabetology \& Metabolic Syndrome 2013 5:47.

\section{Submit your next manuscript to BioMed Central and take full advantage of:}

- Convenient online submission

- Thorough peer review

- No space constraints or color figure charges

- Immediate publication on acceptance

- Inclusion in PubMed, CAS, Scopus and Google Scholar

- Research which is freely available for redistribution 